\title{
19-Year-Old Construction Laborer Crushed in Trench Collapse While Laying Sewage Pipe
}

\section{CASE SUMMARY}

On Thursday, June 11, 2015, a 19-year-old construction laborer (the victim), a construction foreman, and three other construction laborers were in a parking lot laying sewage pipe in a trench. The trench measured a depth of 12 feet 2 inches and covered an area of 5 feet by 48 feet. A trench box measuring 8 feet deep and covering an area of 2 feet 1 inch by 16 feet had been placed into the trench. The trench box walls were 4 feet 2 inches too short and left the construction laborers vulnerable to a large section of the spoil pile and concrete above. The two construction laborers were laying sewage pipe in the trench for approximately 6 hours when an above section of the spoil pile and concrete gave way, dumping the majority of the spoil pile into the trench, burying the victim and trapping the other construction laborer from the waist down. Three construction laborers outside the trench witnessed the incident and immediately contacted Emergency Medical Services at

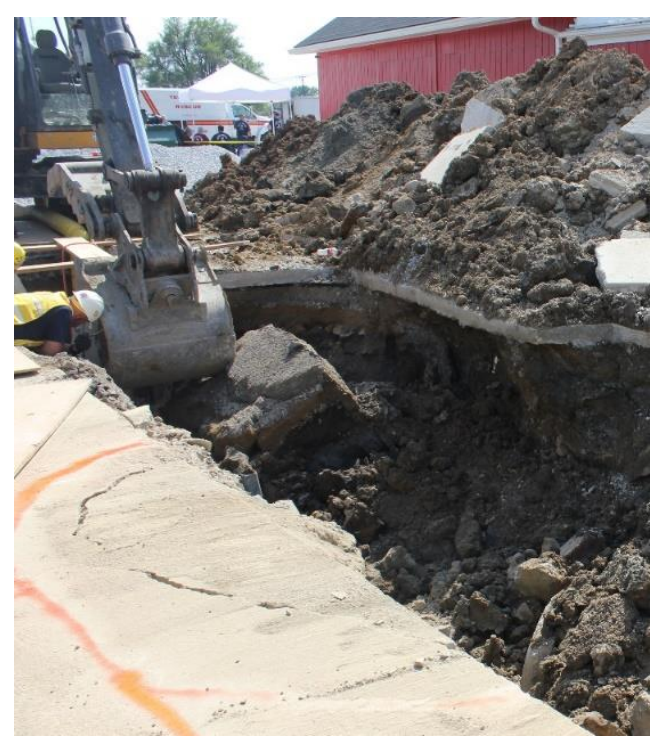

Figure 1. Trench following the rescue efforts. 2:22 pm. While waiting for the EMS to arrive, a worker climbed into the trench and began clearing the debris in an attempt to free the construction laborers. EMS and a special trench rescue team arrived at the scene within eight minutes, at 2:30 pm, to begin the rescue and recovery process. The trapped second construction laborer was alert, calm, and responsive throughout the extraction process, while the victim showed no signs of verbal responsiveness and was entirely covered by debris. The trapped second construction laborer was extracted after four and a half hours and transported to a local hospital for treatment, while the victim required two additional hours of extraction and was pronounced dead at the scene.

Recommendations for prevention:

- Trench boxes used in excavation projects should have a wall height greater than or equal to the wall height of the surrounding trench.

- Pre-job site hazard analysis should be performed before work commences. 
- Employers should ensure a trained, competent person is on the jobsite prior to starting work and that they receive regular refresher training in order to maintain competent person status.

- Employers should ensure all employees receive proper trench safety training.

\section{EMPLOYER}

The employer was a small out-of-state construction company with 5 employees that opened for business in 2009. The foreman had been employed with the company for 10 years; one construction laborer had been employed for 1 year and the three other construction laborers were young men who had been hired the previous month.

\section{SAFETY AND TRAINING PROGRAMS}

The employer did not produce any written safety programs and none of the five employees had been trained on trench safety procedures. The foreman, who was the designated competent person on site, stated he had received trench and excavating training 10-11 years prior to the incident.

The company had a written health and safety manual that included a section entitled "Trenching/Excavation Program". This program stated that all employees who work in trenches should be trained on the hazards associated with trench work, and specifically referenced the requirements found in 29 CFR 1926 Subpart P.

\section{VICTIM}

The victim was a 19-year-old high school graduate, who had been employed with the company for one month as a general construction laborer. He was also a private first class serving his country.

\section{INCIDENT SCENE}

The incident scene was a concrete parking lot with signs of fissures and tension cracks. Signs of previous utility work and excavation in the parking lot were present in the form of previous cut lines and re-set concrete. A trench (measuring 12 feet and 2 inches deep by 5 feet wide by 48 feet long) was located $171 / 2$ feet from the wall of an adjacent building and 34 feet from an active railroad. Following the collapse, a spoil pile measuring $71 / 2$ feet tall was found to be directly on the edge of the trench. The crew stated that the spoil pile had been at least 2 feet from the edge of the trench prior to the collapse. Photographs of the collapse show the spoil pile directly at the edge of the trench, suggesting the 2 foot section of dirt and concrete may have given way. 

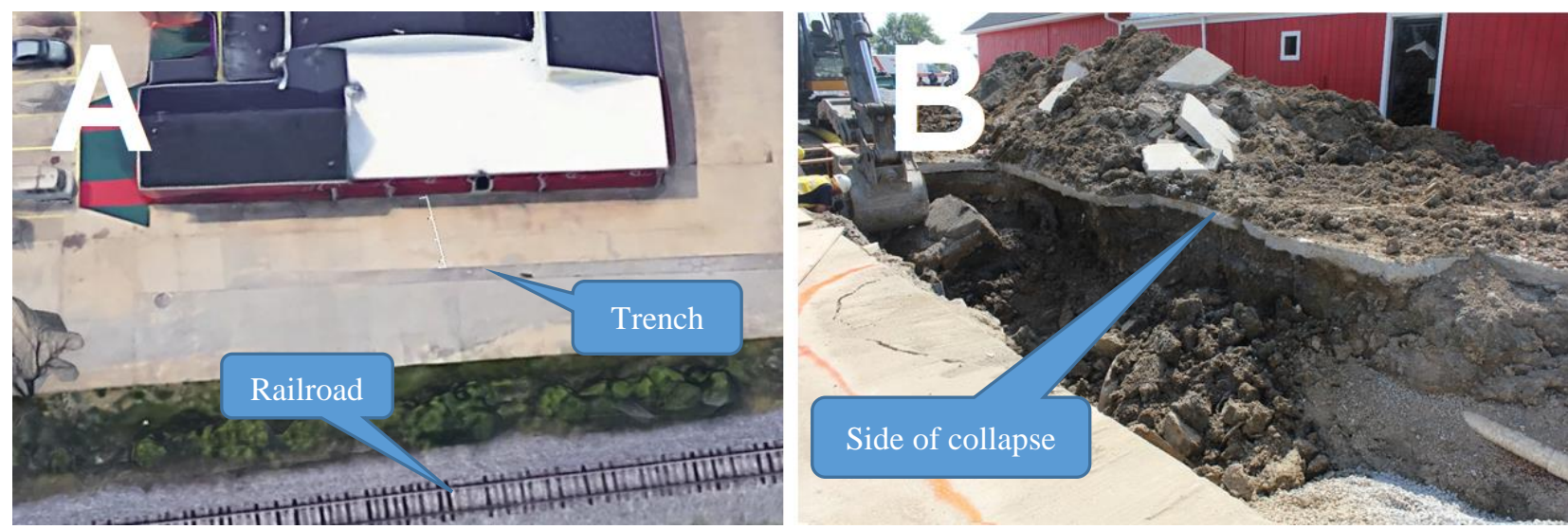

Figure 2. A) Aerial view of the parking lot where the trench collapse occurred; B) the trench from ground level.

\section{EQUIPMENT}

A trench box measuring 8 feet high and covering a ground surface area of 2 feet and 1 inch by 16 feet was used inside of the trench.

Although the workers used a trench box, it was not tall enough for the trench. The trench was 12 feet and 2 inches deep, while the trench box measured only 8 feet tall. This left the construction laborers inside the trench vulnerable to 4 feet and 2 inches of exposed wall.
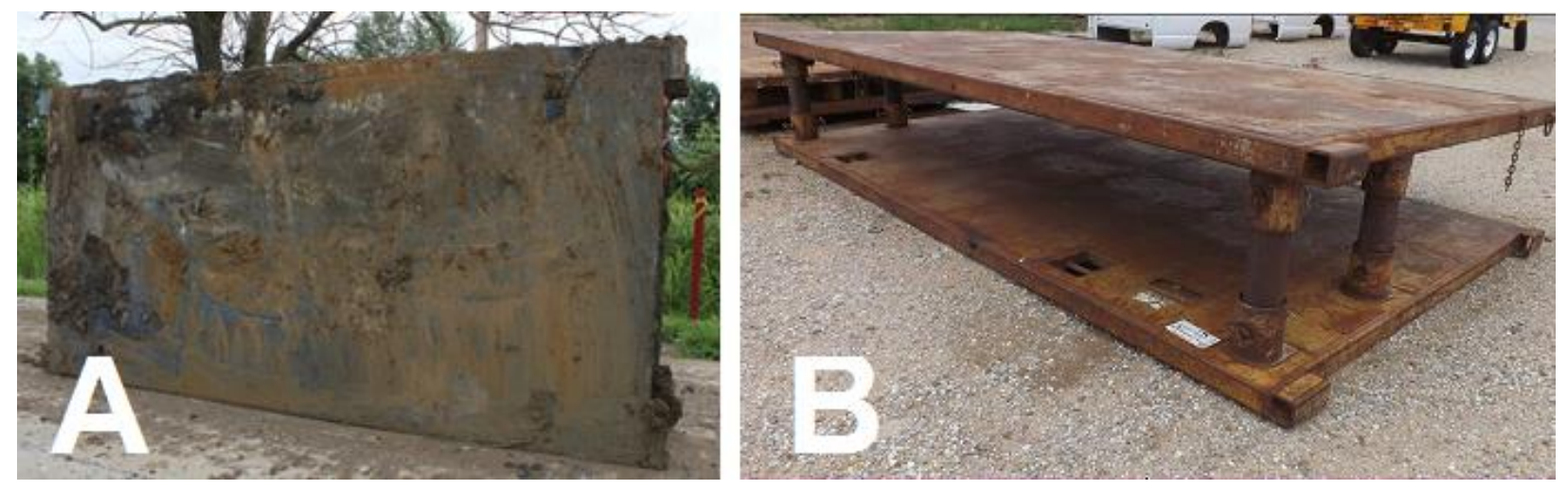

Figure 3. A) Trench box used to protect the workers, the walls of which were 4 feet and 2 inches too short for the job; B) stock photo of the type of trench box used, side angle view.

\section{WEATHER}

June 11,2015 was a mostly cloudy day and the outside temperature was $91^{\circ} \mathrm{F}$, with humidity at approximately $38.5 \%$. Weather was not considered to be a factor in this fatality.

\section{INVESTIGATION}

On June 12, 2015, the Kentucky Labor Cabinet notified the Kentucky Fatality Assessment and Control Evaluation (FACE) Program of a fatality involving a trench collapse that occurred June 11, 2015. An investigation was subsequently conducted. 
An out-of-state construction company had been hired to install 191 feet of sanitary sewage piping for a new business that was being constructed. The crew consisted of one construction foreman and 4 construction laborers.

In order to install the sewage piping, a vertical trench with a depth of 12 feet, 2 inches and an area of 5 feet by 48 feet was dug in a parking lot, $171 / 2$ feet away from a business. The construction company had been on the job site for two weeks and working in the trench for 3-4 days. No pre-job soil test was performed to determine what type of protective system would be necessary. The parking lot surrounding the trench showed fissures and tension cracks, as well as signs of previous excavation. The ground surrounding the trench was subject to vibration from heavy equipment and an active railway was located 34 feet away from the side of the trench away from the building. The foreman rented a trench box with a wall measuring 8 feet tall and an area of 2 feet and 1 inch wide and 16 feet long from a local equipment rental company. When placed into the trench, the trench box was 4 feet and 2 inches below the grade of the vertical walls of the trench.

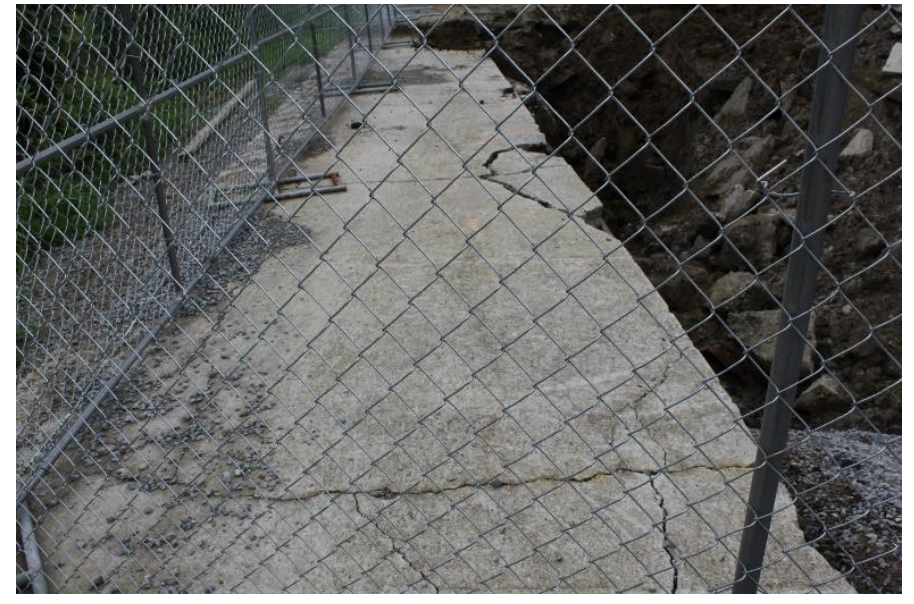

Figure 4. The parking lot surrounding the trench, with fissures and cracks.

On the day of the incident, two of the construction laborers had been laying pipe in the trench for approximately 6 hours. At 2:20 pm, a large section of the trench edge broke off, dumping a portion of the spoil pile and concrete into the trench on top of both construction laborers. The victim was completely buried, while the other construction laborer was trapped from his waist down. Emergency Medical Services (EMS) was called at 2:22 pm and one of the construction crew members climbed into the trench and

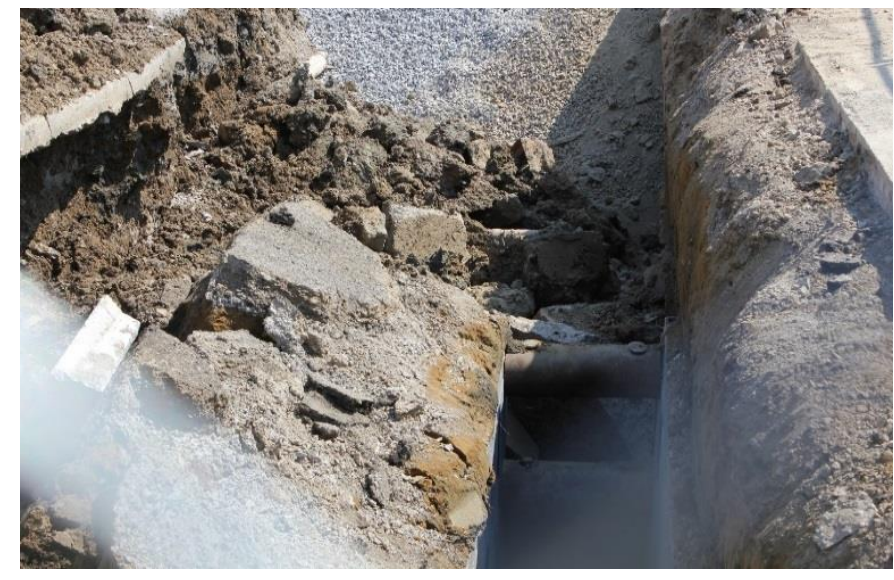

Figure 4. The trench following the collapse. attempted to free the trapped construction laborers. A special rescue trench team arrived at 2:30 pm with EMS and began the rescue and recovery process. The construction laborer who was trapped from the waist down remained calm and responsive during the four and a half hour extraction process until he was freed at $6: 55 \mathrm{pm}$ and taken to a local hospital for treatment of his injuries. The victim's body was recovered two hours later at 8:55 pm. He was pronounced dead at the scene due to traumatic asphyxia and blunt force injuries of the head, neck, and torso. It is unknown how long the victim was buried beneath the debris before succumbing to his injuries. 


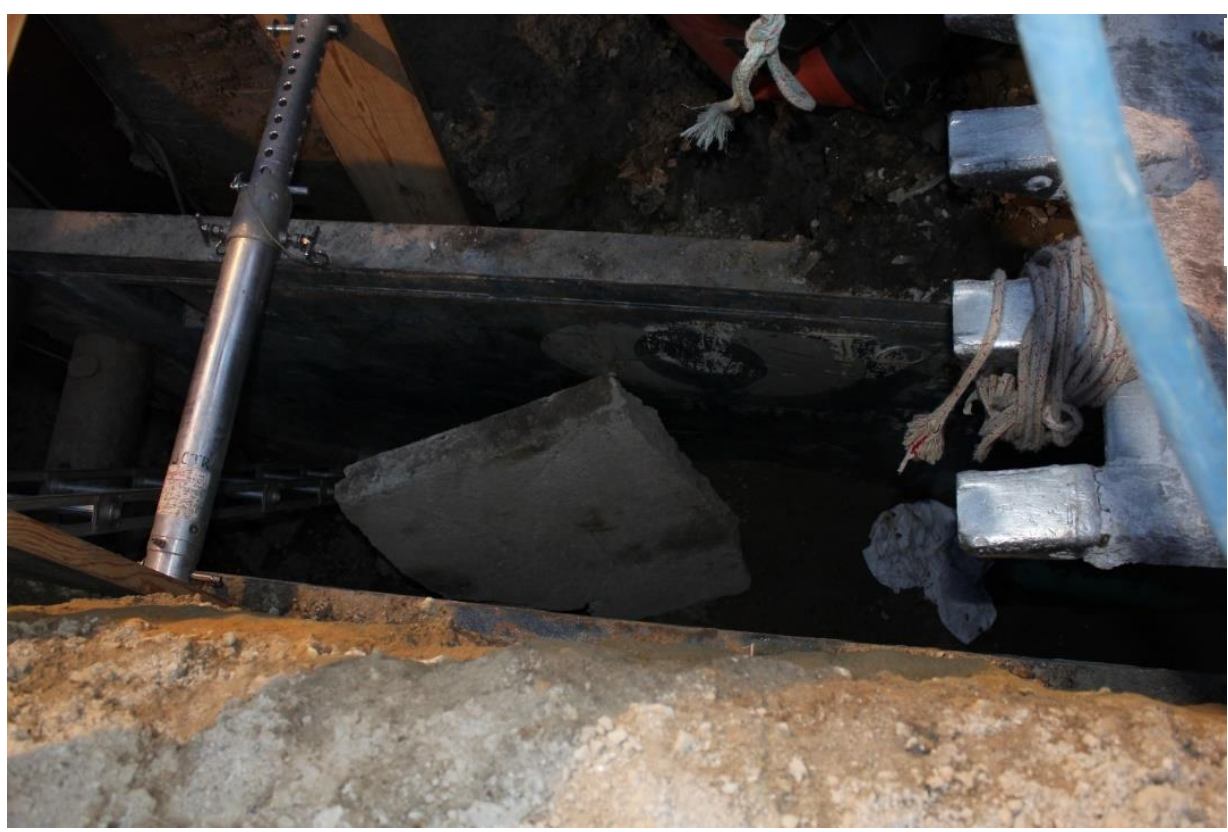

Figure 5. The trench during the rescue and recovery process.

\section{Lack of Proper Soil Test}

Soil testing and classification should have been conducted prior to allowing work to take place within the trench, as it may have identified the poor stability of the ground and indicated the necessary protective system. The stability of the soil in this area was likely weakened by previous excavation at the same location, as evidenced by fissures, cracks, and re-set concrete. The ground at the site also was subject to heavy vibrations from equipment use and a nearby active railway.

\section{Ladder for Safe Ingress and Egress}

Throughout the day, an extension ladder had been used for construction laborer egress and ingress in the trench. Moments before the collapse, the ladder was removed to allow the crew to take measurements within the trench. While the ladder removal was not directly related to the death of the construction laborer, OSHA regulations require the provision of safe egress and ingress for a trench measuring greater than 4 feet in depth. ${ }^{1}$

\section{CAUSE OF DEATH}

The cause of death was traumatic asphyxia with blunt impact injuries of the head, neck and torso. 


\section{CONTRIBUTING FACTORS}

The investigation identified the following factors that may have contributed to the fatality:

- No soil test was performed

- Spoil pile was too close to the edge of the trench and soil retaining system was not used

- Failure to perform scaling the spoil pile to remove unstable rock

- The trench box was not high enough for the excavation site

- Vibrations from heavy equipment use and a nearby active railway may have destabilized the soil

- Previous excavation projects where the trench work was taking place may have destabilized surrounding concrete and soil

- No competent person was on the jobsite

- No daily inspection of the jobsite was performed

- Employer did not provide hazard recognition training

\section{RECOMMENDATIONS AND DISCUSSIONS}

Recommendation No. 1: Trench boxes used in excavation projects should have a wall height greater than or equal to the wall height of the surrounding trench. ${ }^{3}$

A trench box protects employees from exposure to soil collapsing into the trench where work is being performed. The trench box wall measured only 8 feet high, while the trench itself measured 12 feet and 2 inches high. This left 4 feet and 2 inches of ground and concrete exposed, placing the workers below at danger of a partial trench collapse. A properly sized trench box could have helped protect the workers from the hazard.

Recommendation No. 2: Pre-job site hazard analysis should be performed before work commences.

The spoil pile was placed too close to the edge of the trench, preventing scaling to remove unstable rock. In order to provide sufficient space between the location of the spoil pile and the edge of the trench, it is recommended the spoil pile should have been placed on the parking lot side rather than by the building. The height of the spoil pile may have been too high by the side of the building.

Pre-job soil testing and classification should be conducted by a competent person to determine the type of protective system required. OSHA requires that employers have a competent person on site to determine the soil type before work is allowed to begin in a trench. ${ }^{2}$ The foreman stated that he had not classified the soil and that he was unsure of the soil type surrounding the trench. Had the soil been properly tested and classified, the construction crew may have selected a larger trench box.

Recommendation No. 3: Employers should ensure a trained competent person is on the jobsite prior to starting work and that they receive regular refresher training in order to maintain competent person status. ${ }^{4}$ 
The foreman was the designated competent person on site at the time of the incident. According to the foreman, he had last received competent person training on trench safety 10 to 11 years prior to the incident. A schedule for refresher training should be maintained and documented to ensure that all competent persons are fully aware of the steps involved in protecting workers during trenching and other hazardous activities. Training should emphasize that, per OSHA regulation, a competent person must remove workers from the work area if evidence shows that a cave-in could possibly occur, if there are indications of failure of protective systems, hazardous atmospheres, or other hazardous conditions are present. ${ }^{5}$

Training should focus on teaching the competent person to do the following:

- Correct any hazards and order employees to leave until they are corrected

- Perform a job hazard analysis prior to work

- Ensure the correct equipment is being used

- Perform soil testing

- Perform daily inspections of the worksite trench, adjacent areas and protective system(s)

- Ensure the spoil pile is two feet from the trench

- Require that employees wear proper personal protective equipment

- Ensure safe means of ingress and egress

Recommendation No. 4: Employers should ensure all employees receive proper trench safety training.

The foreman stated the company had provided a written Health \& Safety Manual that included trenching and excavation and that he had been trained in excavation safety 10-11 years ago. The company could not provide documentation of training for any of the construction laborers on the job site that day. When interviewed, the construction laborers said they had not received training. Sufficient training demonstrating how to identify potential hazards in the workplace and work in a safety-conscious manner should be provided to each employee prior to their first day of employment.

Please take the time to complete our brief survey regarding this report: (https://uky.az1.qualtrics.com/jfe/form/SV_1MoEKw02zwQ4QQJ)

\section{KEYWORDS}

Trench work

Excavating

Construction

Trench Collapse 


\section{REFERENCES}

${ }^{1}$ Specific Excavation Requirements. 29 CFR 1926.651(c)(2). Occupational Safety and Health Administration.

[https://www.osha.gov/pls/oshaweb/owadisp.show_document?p_table=STANDARDS\&p_id=10 775]

${ }^{2}$ Soil Classification. 29 CFR 1926 Subpart P App A(c). Occupational Safety and Health Administration.

[https://www.osha.gov/pls/oshaweb/owadisp.show_document?p_table=STANDARDS\&p_id=10 931]

${ }^{3} 29$ CFR 1926 OSHA Standards for the Construction Industry, Second Edition. Subpart P Excavations. 2009. Print.

${ }^{4}$ Training Requirements in OSHA Standards. Occupational Safety and Health Administration. [https://www.osha.gove/Pulications/osha2254.pdf]

${ }^{5}$ Specific Excavation Requirements. 29 CFR 1926.651(k)(2). Occupational Safety and Health Administration.

[https://www.osha.gov/pls/oshaweb/owadisp.show_document?p_table=STANDARDS\&p_id=10 775]

${ }^{6}$ Excavations: Safe Practices for small Business Owners and Contractors. Pg. 14. Oregon Occupational Safety and Health Administration.

[http://www.cbs.state.or.us/osha/pdf/pubs/2174.pdf]

${ }^{7}$ Sloping and Benching. 1926 CFR Subpart P App B. Occupational Safety and Health Administration.

[https://www.osha.gov/pls/oshaweb/owadisp.show_document?p_table=STANDARDS\&p_id=10 932]

\section{PHOTO CREDIT}

Photo credit goes to KY OSH and Google Maps.

\section{ACKNOWLEDGEMENTS}

The Kentucky FACE program would like to thank KY OSH and the county coroner for their assistance with this report.

\section{PROGRAM FUNDING}

The Kentucky Fatality Assessment \& Control Evaluation Program (FACE) is funded by grant 2U60OH008483-11 from the Centers for Disease Control and Prevention and the National Institute for Occupational Safety and Health. 
This case report was developed by the Kentucky Fatality Assessment and Control Evaluation (FACE) Program. Kentucky FACE is a NIOSH-funded occupational fatality surveillance program with a goal of preventing fatal work injuries by studying the worker, the work environment, and the role of management, engineering, and behavioral changes in preventing future injuries. The FACE Program is located within the Kentucky Injury Prevention and Research Center (KIPRC), part of the University of Kentucky's College of Public Health.

\section{Email: kyfaceprogram@uky.edu | Telephone: 859-257-5839 333 Waller Avenue Suite 242, Lexington, KY 40504}

Electronic access to this full report can be found here:

(http://www.mc.uky.edu/kiprc/programs/face/files/15KY031.pdf)

\section{FACE on Social Media:}

https://www.facebook.com/Kentucky-FACE-Program$\underline{134135740092906 / \text { ? view_public_for }=134135740092906}$ 